\title{
Analisis dan Strategi Pengentasan Kemiskinan Di Provinsi Jambi
}

\author{
Ahmad Soleh \\ STIE Muhamammadiyah Jambi
}

\begin{abstract}
The growing number of poor population is still a major problem from the Government and it is a very difficult problem to overcome. This is because it is affected by a high population growth without the availability of supported employment in addition also influenced the low HUMAN RESOURCES from the society. In percentage of visible existence of decrease in the number of poor population but in the amount of an increase in the poor population. On the basis of it then this research aims to analyze the two things are pretty important in this poverty reduction efforts among them; (1) how much poverty level happened in the provinces of Jambi and (2) the policy strategy for what could be applied in lowering poverty levels.

In analyzing this problem used two approaches namely quantitative and qualitative methods to explain the results of analysis to make it more clear and easy to understand. The results showed that the number of poor population in the province of Jambi was still not stable (fluctuating) with amount still average more than 8 percent of the total population. As for the strategies that can be applied in reducing poverty can be done in a way; new economic development, microfinance institutions, and competency-based education.
\end{abstract}

Keywords: Poverty, the poverty reduction Strategy.

\section{Pendahuluan}

Secara umum diketahui bahwa pertumbuhan ekonomi merupakan salah satu indikator keberhasilan pembangunan. Sedangkan tujuan yang paling penting dari suatu pembangunan adalah pengurangan tingkat kemiskinan dan penciptaan lapangan kerja yang dapat dicapai melalui pertumbuhan ekonomi dan/atau melalui redistribusi pendapatan. Hal ini dilandasi pada teori trickle-down effect yang dikembangkan pertama kali oleh Arthur Lewis (1954) dan diperluas Ranis dan Fei (1968). Teori trickle-down effect menjelaskan bahwa kemajuan yang diperoleh oleh sekelompok masyarakat akan sendirinya menetes ke bawah sehingga menciptakan lapangan kerja dan berbagai peluang ekonomi yang pada gilirannya akan menumbuhkan berbagai kondisi demi terciptanya distribusi hasil-hasil pertumbuhan ekonomi yang merata. Teori tersebut mengimplikasikan bahwa pertumbuhan ekonomi akan diikuti oleh aliran vertikal dari penduduk kaya ke penduduk miskin yang terjadi dengan sendirinya. Manfaat pertumbuhan ekonomi akan dirasakan penduduk kaya terlebih dahulu, dan kemudian pada tahap selanjutnya penduduk miskin mulai memperoleh manfaat ketika penduduk kaya mulai membelanjakan hasil dari pertumbuhaan ekonomi yang telah diterimanya.

Dengan demikian, maka pengaruh pertumbuhan ekonomi terhadap penuruan angka kemiskinan merupakan efek tidak langsung oleh adanya aliran vertikal dari penduduk kaya ke penduduk miskin. Hal ini berarti juga bahwa kemiskinan akan berkurang dalam skala yang sangat 
kecil bila penduduk miskin hanya menerima sedikit manfaat dari total manfaat yang ditimbulkan dari adanya pertumbuhan ekonomi. Kondisi ini dapat membuka peluang terjadinya peningkatan kemiskinan sebagai akibat dari meningkatnya ketimpangan pendapatan yang disebabkan oleh pertumbuhan ekonomi yang lebih memihak penduduk kaya dibanding penduduk miskin. Pertumbuhan ekonomomi, kemiskinan dan pengangguran merupakan suatu masalah yang sangat serius di Indonesia saat ini, secara teori rendahnya pertumbuhan ekonomi memberikan dampak yang negatif terhadap tingkat pengangguran dan kemiskinan di suatu negara. Berdasarkan data yang ada, jumlah pengangguran dan kemiskinan di Indonesia mengalami penurunan setiap tahunnya. Namun meski jumlah pengangguran dan kemiskinana mengalami penurunan, jumlah pengangguran dan penduduk miskin masih cukup besar, sehingga menimbulkan pertanyaan apakah pembangunan yang selama ini dilaksanakan oleh pemerintah mengalami kegagalan. Demikian halnya yang terjadi padda pemerintahan Provinsi Jambi, dimana tingkat kemiskinan masih tinggi dan masih tersebar diseluruh Kabupaten dan Kota di provinsi ini. Berdasarkan data dari Badan Pusat Statistik (BPS) Provinsi Jambi menunjukkan bahwa persentase tingkat kemiskinan dalam 3 tahun terakhir mangalami kenaikan. Dimana jumlah penduduk miskin mengalami peningkatan sebesar 8,8 persen pada tahun $2015,8,4$ persen pada tahun 2016 dan 8,1 persen pada tahun 2017 atas dasar permasalahan tersebut maka penulis ingin menganalisa tentang (1) berapa besar tingkatan kemiskinan daerah untuk Provinsi Jambi; dan (2) Strategi apa yang tepat dalam pengentasan kemiskinan tersebut.

\section{Tinjauan Pustaka Konsepsi Kemiskinan}

Kemiskinan merupakan suatu kondisi dimana seseorang atau sekelompok orang, laki laki dan perempuan, tidak terpenuhi hak-hak dasarnya secara layak untuk menempuh dan mengembangkan kehidupan yang bermartabat. Cara pandang kemiskinan ini beranjak dari pendekatan berbasis hak yang mengakui bahwa masyarakat miskin, baik laki-laki maupun perempuan, mempunyai hak-hak dasar yang sama dengan anggota masyarakat lainnya. Kemiskinan tidak lagi dipahami hanya sebatas ketidakmampuan ekonomi, tetapi juga kegagalan pemenuhan hak-hak dasar dan perbedaan perlakuan bagi seseorang atau sekelompok orang, laki-laki dan perempuan, dalam menjalani kehidupan secara bermartabat.

\section{Kemiskinan Absolut}

Pada dasarnya konsep kemiskinan absolut ini bermaksud memberi indikator mengenai keadaan perekonomian suatu daerah yang sebagian penduduknya mendapatkan nafkah yang hanya dapat dipakai untuk memenuhi taraf kehidupan minimum (Komaruddin, 1991). Konsep ini memberi arti bahwa kemiskinan absolut berhubungan erat dengan pemenuhan kebutuhan dasar minimum agar seseorang dapat hidup layak. Jika seseorang mempunyai pendapatan dan tidak dapat dipakai untuk memenuhi kebutuhan dasar minimum, maka orang tersebut dikatakan miskin. Tingkat pendapatan minimum sering disebut juga garis batas kemiskinan. Konsep ini acapkali dipakai untuk 
menentukan tingkat pendapatan minimum yang dapat dipakai seseorang untuk memenuhi kebutuhannya akan makan pakaian dan perumahan yang diharapkan mampu menjamin kehidupannya (Todaro, 1989). Sayogyo (1971), misalnya, menggunakan tingkat konsumsi ekuivalen beras per kapita sebagai indikator kemiskinan. Dia membedakan tingkat ekuivalen konsumsi beras di daerah pedesaan dan perkotaan. Untuk daerah pedesaan, apabila seseorang hanya mengkonsumsi ekuivalen beras kurang dari $240 \mathrm{~kg}$ per kapita per tahun, maka yang bersangkutan digolongkan sangat miskin, sedangkan untuk daerah perkotaan ditentukan sebesar ekuivalen $360 \mathrm{~kg}$ beras per kapita per tahun.

\section{Kemiskinan Relatif}

Konsep kemiskinan absolut di atas telah mernbicarakan kriteria yang dapat menentukan apakah seseorang atau kelompok tertentu dapat dikategorikan miskin atau tidak. Pada prinsipnya, orang yang sudah mempunyai pendapatan dan pendapatannya dapat dipakai untuk memenuhi kebutuhan dasar minimum, maka yang bersangkutan dikatakan tidak miskin. Namun demikian banyak ahli berpendapat bahwa walaupun pendapatan seseorang sudah mencapai tingkat kebutuhan dasar minimum,tetapi masih jauh lebih rendah dibandingkan dengan keadaan masyarakat disekitamya, maka orang tersebut masih berada dalam keadaaan miskin (Todaro, 1989 dan Komaruddin, 1991). Konsep kemiskinan relatif biasanya bersifat dinamis, Sehingga kemiskinan akan selalu ada. Kriteria ini akan nampak bila kita mengamati distribusi pendapatan masyarakat.

\section{Konsepsi Kemiskinan Perkotaan}

Kemiskinan

perkotaan mempunyai fenomena multi dimensi meliputi rendahnya tingkat pendapatan, kesehatan dan pendidikan, kerawanan tempat tinggal dan pribadi, dan ketidakberdayaan. Hal tersebut mengakibatkan penduduk miskin perkotaan tinggal di pemukiman yang kumuh dan padat sehingga mengalami kesulitan dalam mengakses fasilitas kesehatan, pendidikan dasar dan kesempatan kerja.Selain itu juga kurang mendapatkan perlindungan sosial dan jaminan keamanan pribadi. Tekanan kemiskinan yang melanda diperparah dengan rendahnya kesadaran warga untuk hidup sehat semakin memperburuk kualitas lingkungan. Berdasarkan dimensi kemiskinan yang telah dijelaskan sebelumnya, penduduk miskin perkotaan memiliki ciri kemiskinan yang paling menonjol di antara karakteristik kemiskinan secara keseluruhan (kemiskinan perkotaan dan pedesaan) yaitu penduduk miskin kota rentan terhadap kemiskinan dan kemiskinan dari segi non-pendapatan dengan penjelasan berikut: (1) Penduduk miskin kota rentan terhadap kemiskinan (kerentanan); (2) Kemiskinan dari segi non-pendapatan (multidimensi); (3) Pemberdayaan sumberdaya manusia; (4) Peningkatan aset dasar masyarakat miskin; (5) Penciptaan dan pengembangan pasar; dan (6) Penciptaan tata kelola pemerintahan yang baik

\section{Indikator Kemiskinan}

Untuk mengetahui jumlah angka kemiskinan dapat digunakan lima versi indikator kemiskinan, sebagai berikut: 
a. Versi Bank Dunia; kemiskinan diukur secara ekonomi berdasarkan penghasilan yang diperoleh orang miskin adalah mereka yang berpendapatan maksimal UU\$ 2 per hari

b. Versi International Labour Organization (ILO); Yaitu orang miskin di pedesaan jika pendapatan maksimal US\$ 0,8 .

c. Versi BKKBN yang mendefinisikan kemiskinan dengan 5 indikator 1) Tidak dapat menjalankan ibadah menurut agamanya, 2) Seluruh keluarga tidak mampu makan dua kali sehari, 3) Seluruh anggota keluarga tidak mempunyai pakaian berbeda untuk di rumah, bekerja, sekolah dan berpergian, 4) Bagian terluas rumahnya terdiri atas tanah, 5) tidak mampu membawa keluarga jika sakit ke sarana kesehatan.

d. Versi Dinas Kesehatan menambahkan kriteria tingkat akses pelayanan kesehatan pemerintah, ada anggota keluarga yang putus sekolah atau tidak, frekuensi makan makanan pokok per hari kurang dari dua kali dan kepala keluarga mengalami pemutusan hubungan kerja atau tidak.

e. Versi BPS mendefinisikan miskin berdasarkan tingkat konsumsi makanan kurang dari 2100 kalori/kapita/per hari dan kebutuhan minimal non makanan (sandang, papan, kesehatan, dan pendidikan). Disamping itu secara ekonomi BPS menetapkan penghasilan Rp. 175.324,- per bulan sebagai batas miskin perkotaan dan Rp. 131.256,- di pedesaan

\section{Metode}

Dalam penelitian ini menggunakan metode kualitatif dan kuatitatif dengan menggunakan data sekunder yang bersumber dari BPS Provinsi Jambi dan artikel artikel lainnya yang terkait.

\section{Model Estimasi Garis Kemiskinan}

Bila agregat data konsumsi, penghasilan atau data non-moneter sudah didapatkan, maka langkah berikutnya adalah menetapkan satu atau lebih garis kemiskinan (poverty line). Garis kemiskinan adalah titik pemisah antara miskin dan tidak miskin, bisa berupa indikator moneter, misal tingkat konsumsi tertentu, atau non-moneter, misal tingkat literasi. Penggunaan garis kemiskinan ganda dapat membantu membedakan tingkat kemiskinan. Umum dipergunakan adalah garis kemiskinan relatif dan garis kemiskinan absolut.

\section{Indeks Keparahan Kemiskinan :} Indeks Keparahan

Kemiskinan (Proverty Severity Index-P2) memberikan gambaran mengenai penyebaran pengeluaran diantara penduduk miskin. Semakin tinggi nilai indeks, semakin tinggi ketimpangan pengeluaran diantara penduduk miskin.

\section{Hasil}

Analisis Jumlah Penduduk Miskin

Kemiskinan bisa dikatakan sebagai indikasi gagalnya kebijakan ekonomi suatu daerah. Disisi lain, kemiskinan justru dapat mencerminkan dampak sampingan dari tumbuh berkembangnya perekonomian Provinsi Jambi. Ketika ekonomi Provinsi Jambi tumbuh menggeliat maka ada kemungkinan meningkatnya urbanisasi dari daerah daerah lain. Keterbatasan yang melekat pada pelaku urbaniasi, akan terimbas pada terjadinya kemiskinan pada kelompok tersebut. Dua kondisi inilah sebagai indikasi awal terjadinya kemiskinan di Provinsi 
Jambi. Berdasarkan untuk lebih jumlah kemiskinan di Provinsi Jambi jelasanya dapat dilihat pada tabel

di bawah ini

Tabel 1

Jumlah penduduk miskin Provinsi Jambi tahun 2010-2017

\begin{tabular}{|c|c|c|}
\hline Tahun & Jumlah Penduduk Miskin (000) & Persentase PendudukMiskin \\
\hline 2010 & 260,50 & 8,40 \\
\hline 2011 & 251,90 & 7,9 \\
\hline 2012 & 270,20 & 8,28 \\
\hline 2013 & 268,50 & 8,41 \\
\hline 2014 & 281,75 & 8,39 \\
\hline 2015 & 300,71 & 8,86 \\
\hline 2016 & 289,81 & 8,41 \\
\hline 2017 & 286,55 & 8,19 \\
\hline
\end{tabular}

Sumber: Kota Jambi Dalam Angka 2018

Fluktuasi peningkatan atau penurunan jumlah penduduk miskin di Provinsi Jambi merupakan fenomena menarik. Secara struktur ekonomi, perekonomian Provinsi Jambi ditompang oleh sektor perdagangan, industri, pertanian dan jasa-jasa. Berarti, terbuka peluang bagi penduduk untuk melakukan aktivitas ekonomi secara lebih luas. Namun demikian ada beberapa hal yang dapat menjelaskanhal ini, yaitu:

1. Peningkatan angka kemiskinan di Provinsi Jambi tidak terlepas dari tingginya angka imigrasi. Ketidak mampuan sektor ekonomi dalam menyerap migrasi masuk dalam lapangan kerja berdampak pada tingkat pendapatan mereka sehingga berujung pada kemiskinan.

2. Meningkatnya angka kemiskinan di Provinsi Jambi dapat juga menggambarkan kemampuan sektor ekonomi dalam peyediaan lapangan kerja. Rendahnya kemampuan daya serap tenaga sektor ekonomi di Provinsi Jambi disebabkan oleh dua hal, antara lain: (a) adanya kecederungan sektor industri atau sektor ekonomi lainnya bersifat capital intensive (padat modal) sehingga lebih rendah kemampuan dalam penyerapan tenaga kerja. (b) Semakin bergerak majunya aktivitas ekonomi Kota Jambi maka terjadi pergerakan akan kebutuhan spesifikasi tenaga kerja. Hal ini yang tidak mampu diikuti oleh tenagakerja yang tersedia.

\section{Garis Kemiskinan}

Garis

kemiskinan merupakan batas pendapatan yang harus dimiliki penduduk perkapita perbulan guna menetapkan status kategori penduduk miskin. Bila pendapatan penduduk diatas garis tersebut, maka penduduk tidak dapat dikategorikan penduduk miskin. Bila pendapatan penduduk dibawah atau sama dengan garis kemiskinan maka penduduk tersebut masuk kategori penduduk miskin. Deskripsi tentang perkembangan garis kemiskinan di Provinsi Jambi dimuat pada tabel dibawah ini. 
Tabel 2

Garis Kemiskinan Kota Jambi 2010-2017

\begin{tabular}{|c|c|}
\hline Tahun & Garis Kemiskinan (Rp/kapita/bulan) \\
\hline 2010 & 253335 \\
\hline 2011 & 258888 \\
\hline 2012 & 273267 \\
\hline 2013 & 307885 \\
\hline 2014 & 329181 \\
\hline 2015 & 343935 \\
\hline 2016 & 371875 \\
\hline 2017 & 389596 \\
\hline
\end{tabular}

Sumber: Hasil Data Olahan Susenas tahun 2017

Paparan data diatas memperlihatkan peningkatan garis kemiskinan yang bergerak searah dengan peningkatan harga barang di Provinsi Jambi. Peningkatan harga tersebut berkaitan dengan inflasi di Provinsi Jambi yang masih dalam kategori tinggi dan terus meningkat.

\section{Indeks Kedalaman dan Keparahan Kemiskinan}

Sejalan dengan peningkatan garis kemiskinan, maka Indeks kedalaman kemiskinan dan kepatahan kemiskinan juga terus meningkat. Pada tahun 2005, indeks kedalaman kemiskinan hanya sebesar
0,73 dan kemudian meningkat menjadi 1,52 pada tahun 2012 atau meningkat sebesar 102,22 selama 7 tahun atau setara pula dengan peningkatan $15,46 \%$ pertahun. Sedangkan indeks keparahan tahun 2005 hanya sebesar 0,15 dan meningkat menjadi 0,44 pada tahun 2012 atau terjadi peningkatan sebesar 193,33\% selama 7 tahun atau juga secara rata-rata meningkat sebesar 27,62\% pertahun. Deskripsi tentang perkembangan indeks kedalaman dan keparahan kemiskinan selama tahun 2005-2012 dimuat pada tabel di bawah ini.

Tabel 3

Indeks kedalaman dan Keparahan Kemiskinan di Provinsi Jambi Tahun 2010-

2017

\begin{tabular}{|c|c|c|}
\hline Tahun & Indeks Kedalaman Kemiskinan (P1) & Indeks Keparahan Kemiskinan (P2) \\
\hline 2010 & 0,92 & 0,29 \\
\hline 2011 & 1,02 & 0,23 \\
\hline 2012 & 1,37 & 0,44 \\
\hline 2013 & 1,12 & 0,26 \\
\hline 2014 & 1,12 & 0,23 \\
\hline 2015 & 1,43 & 0,35 \\
\hline 2016 & 1,47 & 0,37 \\
\hline 2017 & 1,28 & 0,29 \\
\hline
\end{tabular}

Sumber: Hasil Data Olahan Susenas tahun 2017

Paparan Tabel 3 diatas memperlihatkan peningkatan fenomenal yang terjadi pada tahun 2011 dan 2012 dimana terjadi kenaikan indeks kedalaman dan keparahan kemiskinan. Berarti di tahun 2012 terjadi peningkatan yang sejalan dengan peningkatan garis 
kemiskinan di Provinsi Jambi. Indeks

kedalaman kemiskinan Provinsi Jambi di tahun 2012 masih berada diatas indeks kedalaman kemiskinan Provinsi Jambi.

\section{Analisis Kebijakan Pengentasan Kemiskinan \\ Kebijakan \\ Pengurangan Kemiskinan \\ Percepatan}

Dalam rangka mengentaskan kemiskinan dan meningkatkan taraf hidup masyarakat sangat diperlukan campur tangan dari pemerintah baik dalam bentuk kebijakan dan strategi yang bertujuan mempermudah dan menyederhanakan proses pengentasan kemiskinan. Disinilah kunci dan peran pemerintah dalam menghilangkan permasalahan dan mengentaskan kemiskinan, dalam hal ini ada dua macam kebijakan yang tepat guna mempercepat pengentasan kemiskinan di Provinsi Jambi diantaranya adalah:

\section{Strategi Lintas Pelaku}

Inti dari strategi ini adalah meningkatkan kapasitas pendapatan penduduk miskin. Jika pendapatan penduduk miskin meningkat maka secara otomatis tingkat kesejahteraan penduduk miskin akan berkurang. Upaya ini dilakukan dengan cara meningkatkan produktifitas penduduk miskin dengan mengembangkan usaha ekonomi mikro yang didukung oleh bantuan modal dalam bentuk kredit yang berasal dari perbankkan sebagai hasil dari kerjasama pemerintah dengan pihak perbankan.

Melalui bantuan tersebut maka usaha mampu tumbuh dan menciptakan kesempatan kerja. Semakin tinggi kesempatan kerja yang ada maka akan lebih cepat proses pengentasan kemiskinan. Selain dalam bentuk bantuan usaha, pemerintah juga harus memberikan dorongan terhadap penduduk miskin dalam hal pengurangan beban ekonomi yang bisa diberikan berbentuk bantuan langsung dan tunai hal ini bertujuan untuk meningkatkan kemampuan ekonomi pada saat mereka balum mulai berproduksi. Strategi yang harus dilakukan oleh pemerintah adalah melalui pemberian perlindungan sosial kepada masyarakat miskin. Jika hal ini dapat dilaksanakan dengan baik maka upaya pengentasan kemiskinan di Kota Jambi ini akan lebih cepat terlaksana dan tingkat kemiskinan di Provinsi Jambi ini akan teratasi. Strategi ini dapat terlihat pada Gambar 1 dibawah ini. 


\section{Gambar 1}

Strategi Lintas Pelaku dalam Pengentasan Kemiskinan

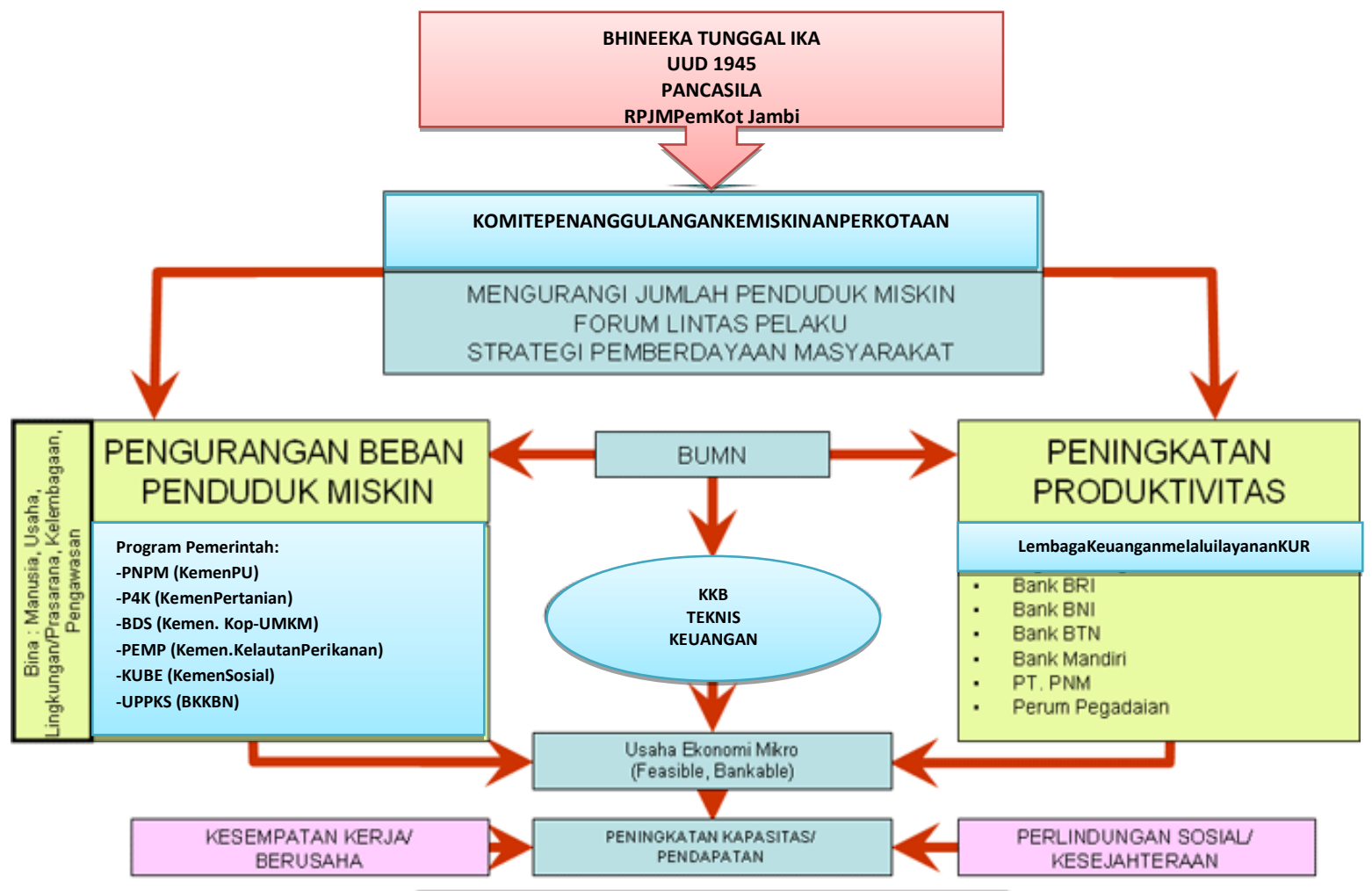

Strategi intervensi ini merupakan stategi mendasar yang sangat penting dalam mengurangi tingkat kemiskinan, karena dengan strategi ini dapat mempersiapkan apa yang seharusnya dilakukan dan kapan strategi yang tepat dapat diambil. Dalam strategi ini intervensi yang dilakukan dibagi dalam tiga kelompok umur.

Kebijakan Terobosan Untuk Pengentasan Kemiskinan

\section{Model Pengembangan Kawasan Ekonomi Baru}

Strategi ini dilakukan dengan cara membentuk kawasan baru (regrouping) dan realokasi penduduk miskin melalui penciptaan kawasan baru atau kawasan ekonomi baru. Kawasan tersebut dibangun untuk mengubah kawasan kumuh dengan penduduk miskin menjadi kawasan baru dengan penduduk yang menuju sejahtera, seperti kawasan penduduk miskin pada kawasan kumuh di Jakarta. 


\section{Gambar 2}

\section{Pengembangan Kawasan Ekonomi Baru untuk Pengentasan Kemiskinan}

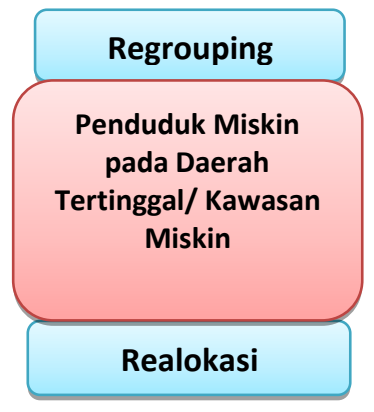

\section{Pengembangan Lembaga Keuangan Mikro}

Pertumbuhan ekonomi yang tinggi telah mendorong masyarakat menjadi konsumtif dan meningkatnya kesenjangan sosial antar golongan ekonomi. Akibatnya, tabungan rendah dan ketahanan sosial ekonomi juga menjadi rendah. Gaya hidup konsumtif rentan terhadap masyarakat menengah kebawah untuk menjadi miskin. Oleh karena itu, diperlukan kebijakan menahan perilaku konsumtif menjadi perilaku menabung pada lembaga keuangan yang mudah diakses, seperti lembaga keuangan mikro, (LKM) khusus untuk golongan ekonomi bawah.

LKM perkotaan tersebut akan membantu penduduk perkotaan yang rentan terhadap kemiskinan untuk menabung dan mendapatkan dana kredit mikro. Untuk itu, LKM dapat pula menjalin kerjasama dengan perbankan yang memiliki layanan kredit mikro seprti Bank Perkreditan Rakyat (BPR) dan Bank Umum yang memiliki jejaring layanan kredit usaha mikro. Melalui skema layanan kredit mikro oleh perbankan, maka akan terjalin usaha yang saling menguntungkan dengan LKM yang anggotanya. Mayoritas penduduk miskin. Ada terjadi mobilisasi dana si sekitar penduduk miskin yang mendorong mereka lebih produktif. Deskripsi yang detil tentang skema pengembangan lembaga mikro untuk pengentasan kemiskinan perkotaan dimuat pada gambar dibawah ini 


\section{Gambar 3}

\section{Pengembangan Lembaga Keuangan Mikro Perkotaan (LKMP) untuk Pengentasan Kemiskinan}
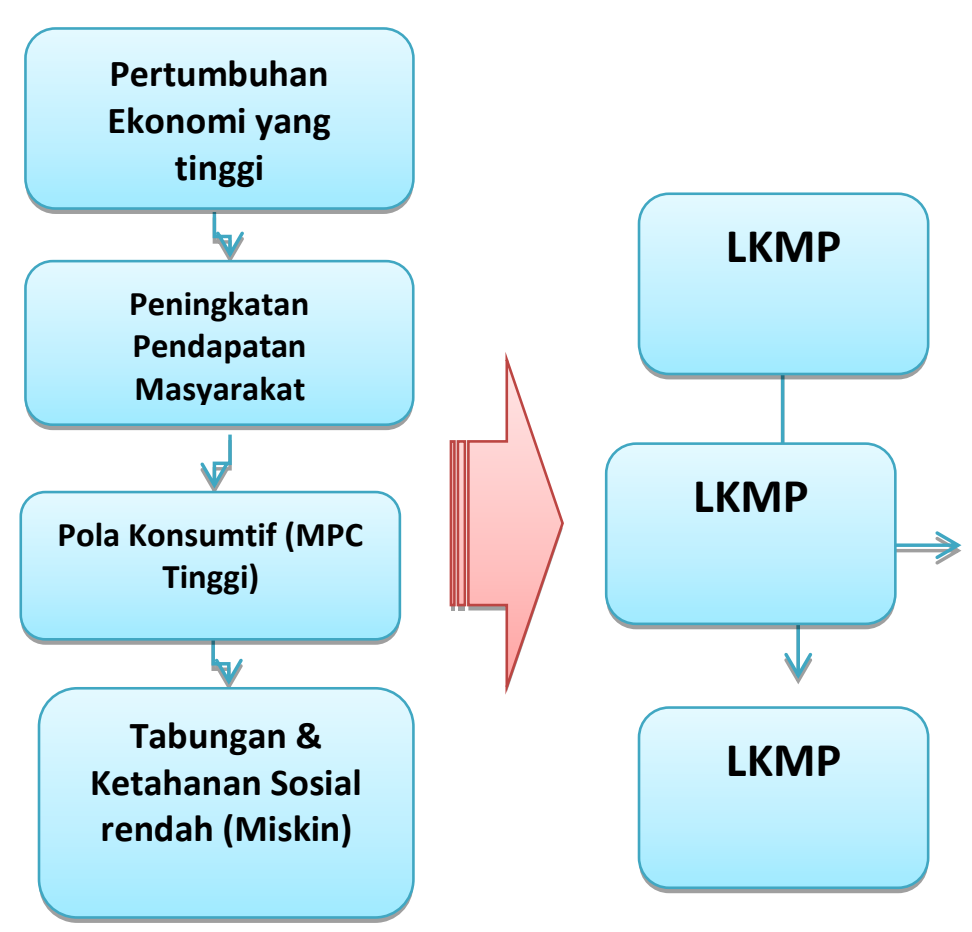

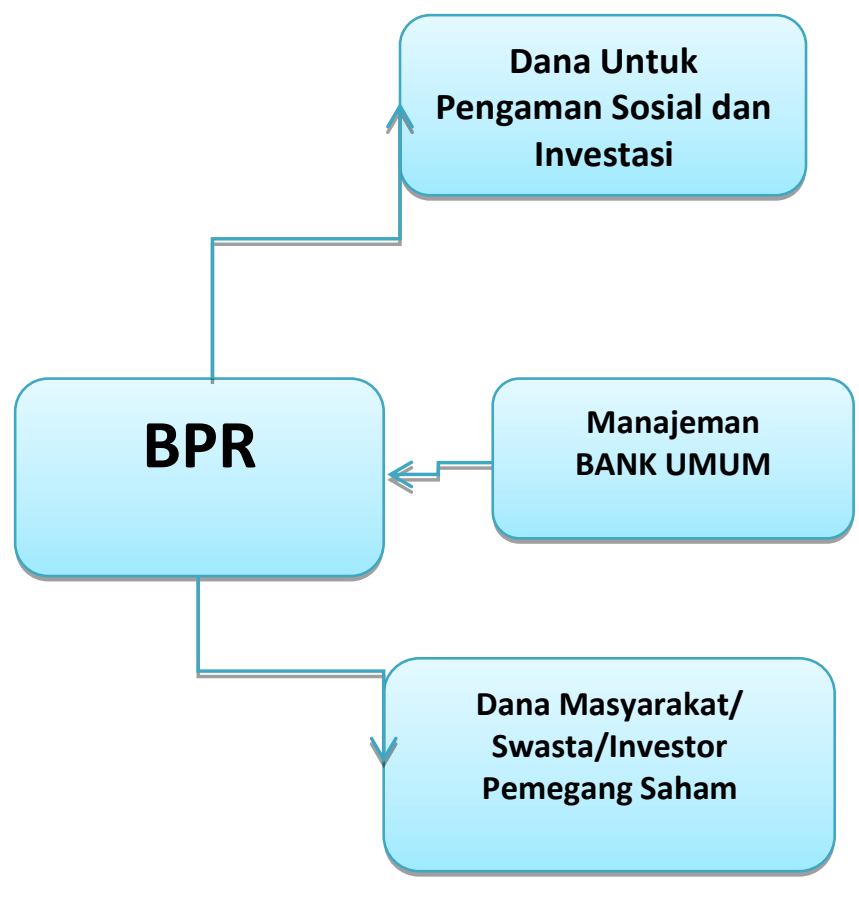

\section{Model Pengembangan Lembaga Pendidikan Berbasis Kompetensi}

Peningkatan kompetensi sumberdaya manusia penduduk miskin diperlukan. Namun peningkatan kompetensi tersebut tidak cukup hanya melalui pendidikan gratis dan wajib belajar 9 tahun. penduduk miskin harus diberi pendidikan yang memiliki kompetensi untuk bekerja dan berusaha yang mampu mengubah kehidupannya. Oleh karena itu, putra-putri penduduk miskin harus diberi jaminan memperoleh pendidikan yang memberi mereka kompetensi untuk bekerja dan berusaha. Pendidikan tersebut adalah SMK (Sekolah Menengah Kejuruan) dan Politeknik D3 yang memberi bekal putra-putra penduduk miskin untuk menciptakan lapangan kerja sendiri atau terampil bekerja pada dunia usaha. Bila putra-putri penduduk miskin sudah terampil dan mandiri maka akan berdampak terhadap ekonomi keluarga penduduk miskin. Peningkatan pendapatan putra-putri tersebut akibat mereka terampil dan mandiri akan meningkatkan pula kesejahteraan keluarganya atau menjadikan keluarganya tidak miskin lagi. Deskripsi lebih detil tentang kebijakan pengembangan lembaga pendidikan SMK dan Politeknik untuk pengentasan kemiskinan dimuat pada gambar berikut ini. 
Gambar 4

\section{Pengembangan Lembaga Pendidikan Berbasis Kompetensi}

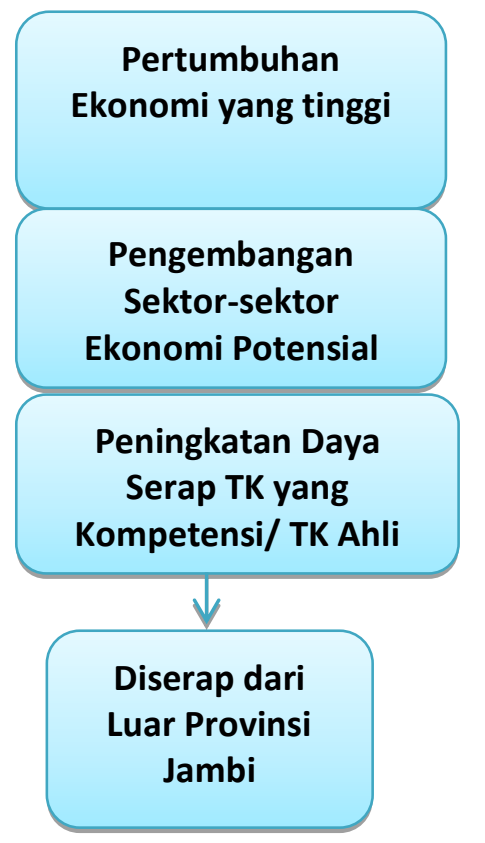

SIMPULAN

Paparan tentang analisis kemiskinan, strategi dan kebijakan pengentasan kemiskinan di Kota Jambi memerlukan perhatian yang lebih serius dari semua pihak. Trend jumlah penduduk miskin Provinsi Jambi cenderung meningkat. Kendati pun secara relative tidak terlihat adanya indikasi menurun dari persentase jumlah penduduk miskin. Kondisi ini diperkuat oleh meningkatnya besaran garis kemiskinan dan indeks kedalaman serta keparahan kemiskinan.

\section{DAFTAR PUSTAKA}

Anonim, 2003. Program Pengentasan Kemiskinan, Kantor Menko Kesra, Jakarta 2004. Strategi Penanggulangan

Kemiskinan Nasional, Kantor Menko Kesra, Jakarta.

2003. Laporan Pendataan Keluarga Propinsi Jambi, BKKBN, Propinsi Jambi.
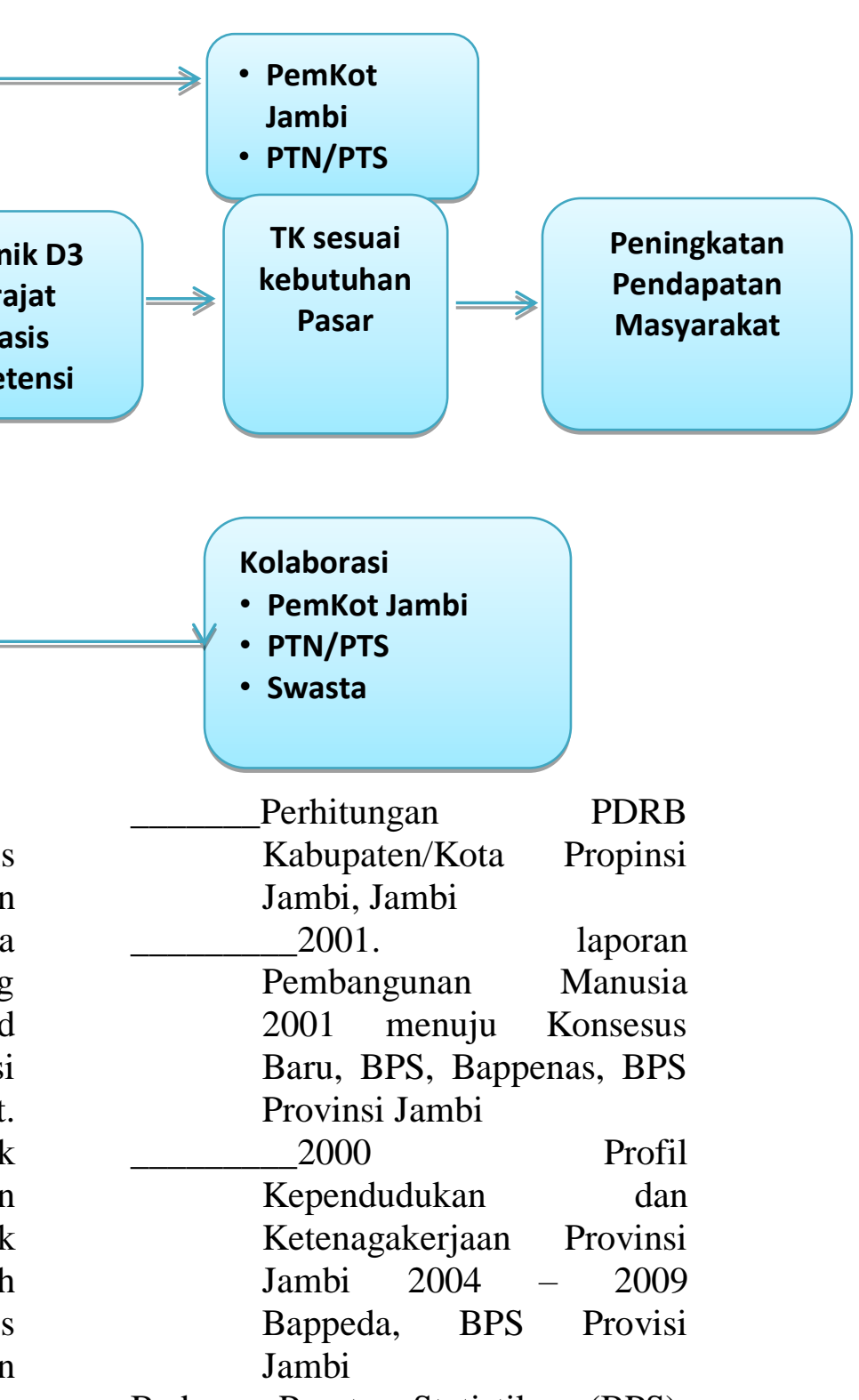

Badan Pusat Statistik (BPS). Kabupaten Provinsi Jambi.

Girsang, W. (2009). Strategi Pengentasan Kemiskinan di Pulau Kecil di Propinsi Maluku. Agrikultura, 20(3).

Irmanelly, I., \& Soleh, A. (2013). Analisis Sektor Unggulan dan Hubungannya dengan Ketenagakerjaan dan Kemiskinan di Provinsi Jambi. Jurnal Development, 1(1), 15-43

Rahayu, Y. (2018). ANALISIS PENGARUH INDEKS 
PEMBANGUNAN

MANUSIA, PDRB PER

KAPITA, DAN JUMLAH

PENGANGGURAN

TERHADAP JUMLAH

PENDUDUK MISKIN DI

PROVINSI JAMBI.

EKONOMIS: Journal of

Economics and Business, 2(1), 165-174.

Ratih, D., \& Sondarika, W. (2017).

ANALISIS POTENSI DESA

DITINJAU DARI SOSIAL

BUDAYA KESENIAN

TRADISIONAL

RONGGENG GUNUNG

DALAM

MENINGKATKAN

PENDAPATAN

MASYARAKAT

PRASEJAHTERA (Studi

kasus di desa Ciulu Kec.

Banjarsari Kab. Ciamis Jawa

Barat). Jurnal Artefak, 4(2), 161-166.

Remi Soemitro Sutyastie dan Tjiptoherijanto prijono, (2002); "Kemiskinan dan Ketidakmerataan di Indonesia",Edisi Indonesia - Inggris, Rineka Cipta,jakarta.

Soleh, Ahmad., (2012); Analisis Pertumbuhan Ekonomi dan Kesenjangan Pembangunan Ekonomi Antar Region Di Indonesia Tahun 2001-2010. Jurnal Ekonomi Dan Perencanaan Pembangunan (JEPP) Volume:04.No.03.

Todaro, M.P., (1998); Pembangunan Ekonomi di dunia ketiga, Edisi keenam, Penerbit Erlangga, Jakarta. 